children. Acta Otolaryngol. 1985 Sep-Oct;100(34):260-5.

8. Rovers $M M^{1}$, Numans $M E$, Langenbach $E_{\text {, }}$ Grobbee DE, Verheij TJ, Schilder AG. (2008),
Is pacifier use a risk factor for acute otitis media? A dynamic cohort study. Fam Pract. 2008 Aug;25(4):233-6. doi: 10.1093/fampra/cmn030. Epub 2008 Jun 17.

\title{
VAI TRÒ CỦA HÚT HUYẾT KHỐI TRONG CAN THIỆP NHỒI MÁU THÂN CẤP NHÂN MộT TRƯờNG HỢP LÂM SÀNG TẠI VIỆN TIM MẠCH VIỆT NAM
}

\author{
Nguyễn Mạnh Quân ${ }^{1,2}$, Ngô Quang Tùng1, \\ Đào Thị Ly ${ }^{1}$, Trương Thị Thanh Bình ${ }^{1}$
}

\section{TÓM TẮT}

Tổng quan: Nhồi máu thận cấp là bênh lý hiếm gặp trên lâm sàng, thường bị bỏ sót hoặc chẩn đoán nhâm lẫn với các tình trang bênh lý khác do biểu hiện lâm sàng đa dạng và không đặc hiệu. Bệnh cân được chẩn đoán sớm và điều trị để tránh làm ảnh hưởng tới chức năng thận. Hiện nay, chưa có khuyến cáo rõ ràng về điêu trị tối ưu cho nhồi máu thận cấp. Can thiệp hút huyết khối qua đường ống thông kèm điêu trị nội khoa phối hợp có thể là một lựa chọn trong chiến lược điêu trị bệnh nhân nhồi máu thân cấp. Phương pháp: Báo cáo ca lâm sang. Kết quả: Chúng tôi báo cáo ca lâm sàng hiếm gặp tại Viện Tim Mạch, Bệnh viện Bạch Mai. Bệnh nhân nam, 34 tuổi nhâp viện vì đau vùng hông lưng trái với huyết khối cấp tính gây tắc nhánh cực trên động mạch thận trái, được chẩn đoán và điều tri kip thời và cho kết quá điều trị tốt. Kết luận: Nhồi máu thận cấp là một bệnh không phổ biến và dễ bị bỏ sót. Việc chọn lựa phướng pháp điều trị phụ thuộc vào từng trường hợp cụ thể.

Tư khoá: Nhồi máu thận cấp, hút huyểt khối.

\section{SUMMARY}

ROLE OF PERCUTANEOUS THROMBECTOMY IN INTERVENTION OF ACUTE RENAL INFARCTION THROUGH A CLINICAL CASE IN VIETNAM NATIONAL HEART INSTITUTE

Background: Acute renal infarction is a rare clinical condition that is often overlooked or misdiagnosed with other medical conditions due to diverse and nonspecific clinical manifestations. The disease needs to be diagnosed early and treated to avoid affecting kidney function. Currently, there are no clear recommendations for optimal treatment for acute renal infarction. Interventional catheter thrombectomy with combined medical therapy may be an option in the treatment strategy of patients with acute renal failure. Methods: A case report. Result: We report a rare clinical case at the Vietnam Heart Institute, Bach Mai Hospital. A 34-years-old male patient was

\footnotetext{
${ }^{1}$ Viện Tim mạch Việt Nam - Bệnh viện Bạch Mai ${ }^{2}$ Trường Đại học Y Dước - Đại học Quốc gia Hà Nội Chịu trách nhiệm chính: Nguyễn Mạnh Quân Email: quannttm@gmail.com Ngày nhận bài: 13.9.2021
}

Ngày phản biện khoa học: 11.11.2021

Ngày duyệt bài: 19.11.2021 admitted to the hospital because of left flank pain with acute thrombosis causing occlusion of the left superior renal artery, which was diagnosed and treated promptly and gave good results. Conclusion: Acute renal infarction is an uncommon and easily missed disease. The choice of treatment method depends on the individual case.

Keywords: Acute renal infarction, thrombectomy

\section{I. ĐĂT VẤN ĐỀ}

Nhồi máu thận cấp là một tình trạng bệnh lý hiếm gặp trên lâm sàng, với tỷ lệ dao động từ 0,7 tới $1,4 \%$ số ca nhập viện khoa cấp cứu vì đau bụng tại Mỹ. Biểu hiện lâm sàng đa dạng, không đặc hiệu làm cho nhồi máu thận cấp thường bị bỏ sót, chẩn đoán muộn hoặc chẩn đoán nhầm lẫn với cơn đau quặn thận và các nguyên nhân gây đau bụng khác, làm ảnh hưởng, thậm chí mất hoàn toàn chức năng thận. Hiện nay, chưa có những khuyến cáo thật sự rõ ràng về lựa chọn điều trị cho nhồi máu thận, chủ yếu là tùy theo kinh nghiệm và khả năng của từng trung tâm. Tuy nhiên, có 3 phương pháp điều trị chủ yếu là: Thuốc chống đông; Can thiệp mạch qua da và Phẫu thuật.

Trong bài viết này, chúng tôi báo cáo về một trường hợp bệnh nhân nhồi máu thận được can thiệp hút huyết khối qua đường ống thông, tiến hành tại Viện Tim Mạch, Bệnh Viện Bạch Mai và bảo tồn được chức nằng thận.

\section{CA LÂM SÀNG}

Bệnh nhân nam, 34 tuổi, tiền sử hút thuốc lá 10 bao/năm, ngoài ra chưa phát hiện bệnh lý gì khác. Bệnh nhân đau vùng hông lưng bên trái dữ dội cách nhập viện 20 tiếng và được chụp CTScanner chẩn đoán: Nhồi máu thận do tắc nhánh động mạch cực trên thận trái.

Tình trạng lúc vào viện: Bệnh nhân tỉnh, còn đau hổng lưng trái âm ỉ, có lúc đau cơn nhiều hơn. Bệnh nhân không sốt, không khó thở.

Khám lâm sàng: Bụng mềm, ấn tức vùng mạn sườn trái, không có phản ứng thành bụng, Tim đều 70 chu kỳ/ phút, phổi không rales, gan 
lách không to. Các cơ quan khác không phát hiện đặc biệt gì.

Cận lâm sàng: Điện tâm đồ là nhịp xoang, tần số 66 lần/phút.

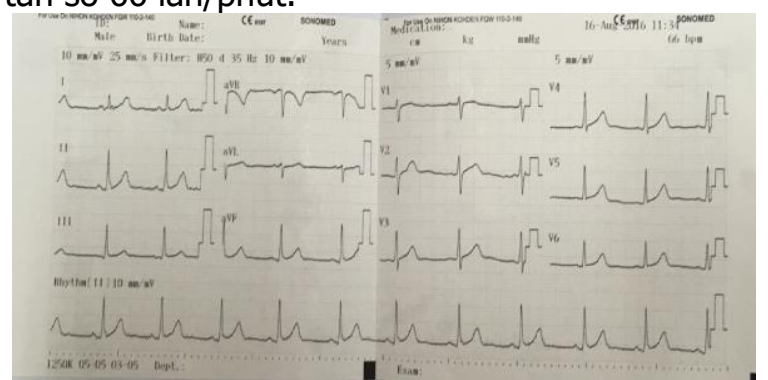

Hình 1: Điện tâm đồ lúc nhập viện của bềnh nhân

Siêu âm tim chức năng tim trong giới hạn bình thường, không có bất thường van tim, không có bệnh lý tim bẩm sinh.

Holter điện tâm đồ bình thường, không ghi nhận cơn rung nhĩ.

Protein $C$, Protein $S$, kháng thể kháng nhân, kháng thể kháng DsDNA âm tính.

Siêu âm mạch chi dưới không có huyết khối động mạch, tĩnh mạch.

Các xét nghiệm sinh hóa, dấu ấn u trong giới hạn bình thường.

Chúng tôi tiến hành chụp động mạch thận qua da qua đường vào động mạch đùi phải, dùng guiding JR4, $6 \mathrm{~F}$ cho hình ảnh tắc nhánh động mạch cực trên thận trái. Sau đó dùng guidewire Runthrough và dụng cụ hút huyết khối Thrombuster II để tiến hành hút huyết khối nhiều lần. Kết quả chụp lại thấy hiện hình lại các nhánh mạch máu của động mạch cực trên thận trái.

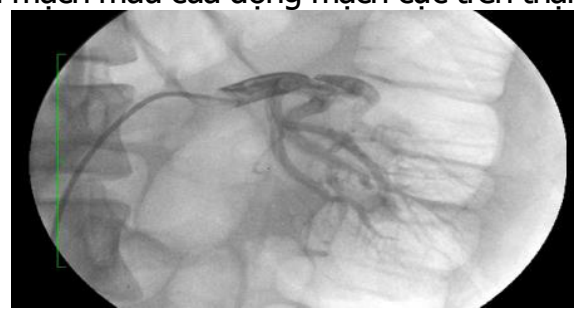

Hình 2. Chụp động mạch thận trái kết quả tăc động mạch cực trên

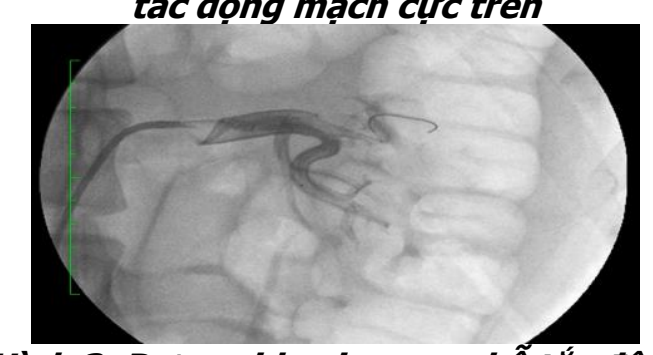

Hình 3. Đưa guidewire qua chố tắc động mạch thận

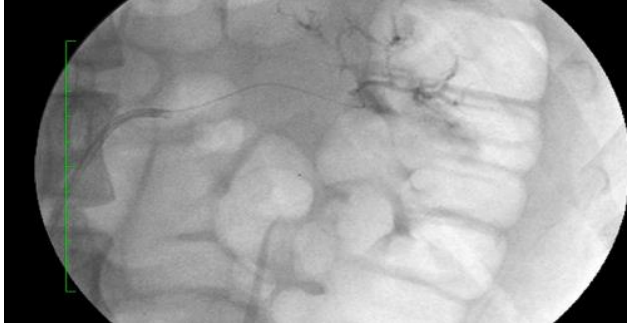

Hinh 4. Kêt quả chụp lại thây tái thông một phân động mạch cực trên thận trái

Bệnh nhân này được điều trị Aspirin $100 \mathrm{mg} /$ ngày, Lovenox $1 \mathrm{mg} / \mathrm{kg} / 12$ giờ trong 5 ngày đầu, sau đó chuyển sang Xarelto $15 \mathrm{mg}, 2$ viên/ ngày trong 21 ngày và Xarelto $20 \mathrm{mg} /$ ngày đến 6 tháng kết hợp với Aspirin 100mg/ ngày. Sau 6 tháng, chỉ dùng Aspirin $81 \mathrm{mg} / \mathrm{ngày}$ đơn độc, kết hợp với kiểm soát huyết áp.

Hiện tại, sau 3 năm theo dõi, bệnh nhân ổn định, huyểt áp và chức năng thận bình thường.

\section{BÀN LUÂN}

Như đã nói phía trên, nhồi máu thận là bệnh lý tương đối hiếm gặp và thường xuyên bị bỏ sót. Tỷ lệ thực tế của bệnh là chưa rõ, tuy nhiên xung quanh khoảng $2 \%$ trong nghiên cứu theo dõi trên 30.000 bệnh nhân có rung nhĩ, theo dõi trong vòng 13 năm. Tỷ lệ thực tế của nhồi máu thận có thể cao hơn con số trong các nghiên cứu vì một lượng lớn bệnh nhân bị bỏ sót [1].

Hai nguyên nhân chính của nhồi máu thận là thuyên tắc từ tim hoặc động mạch chủ và huyết khối tại chỗ. Trong phẩn lớn các trường hợp, nguồn thuyên tắc chủ yếu từ tim. Rung nhî, nhồi máu cơ tim, hẹp 2 lá hậu thấp, huyết khối từ van tim nhân tạo, mảng sùi trong viêm nội tâm mạc nhiễm khuẩn đều là các nguyên nhân thường gặp. Ngoài ra, các tình trạng tăng đông như: Hội chứng kháng phospholipid, đa hồng cầu, hội chứng thân hư cũng là những yếu tố nguy cơ lớn của nhồi máu thận. Nhồi máu thận cũng có thể gặp liên quan đến các thủ thuật can thiệp động mạch chủ, can thiệp mạch thận.

Một số nguyên nhân khác như: Chấn thương thận, bất thường mạch thận ( mạch thận xoắn vặn, phình mạch..) hoặc nhồi máu thận không rõ nguyên nhân [1], [2].

Biểu hiện lâm sàng của nhồi máu thận không đặc hiệu. Đa số bệnh nhân có biểu hiện đau vùng hông lưng, thường kèm theo sốt, buồn nôn và nôn. Thiểu niệu thường ít gặp. Đôi khi bệnh nhân còn biểu hiện tăng huyết áp cấp tính, nguyên nhân có thể trung gian qua renin. Các biểu hiện này cũng có thể gặp trong các bệnh lý bụng khác và cần chẩn đoán phân biệt. 
Bệnh nhân nhồi máu thận có thể có tăng số lượng bạch cầu, creatinin có thể bình thường hoặc tăng tùy theo mức độ nhồi máu thận. Creatinin tăng cao thường gặp trong nhồi máu mạch lớn hoặc nhồi máu thận 2 bên. Cũng có thể thấy hồng cầu niệu đại thể hoặc vi thể khi xét nghiệm nước tiểu. Lactate Dehydrogenase tăng cao, thường gấp 2- 4 lần giới hạn trên bình thường và tăng ít hoặc không tăng các aminotransferase, trong bệnh cảnh lâm sàng phù hợp cũng gợi ý nhồi máu thận. Trong nghiên cứu của Ze'ev Korzets, $100 \%$ bệnh nhân nhồi máu thận có tăng cao LDH [3].

Siêu âm mạch thận, chụp cắt lớp vi tính, cộng hưởng từ với gadolinium hoặc chụp mạch thận qua da đều có thể sử dụng, trong đó, chụp mạch thận vẫn là tiêu chuẩn vàng [4].

Điều trị tối ưu cho các trường hợp nhồi máu thận chưa rõ ràng do chưa có các nghiên cứu so sánh lớn và ngẫu nhiên.

Một số chiến lược điều trị bao gồm: Thuốc chống đông, can thiệp nội mạch (hút huyết khối, tiêu sợi huyết qua đường ống thông kèm/ không kèm theo đặt stent) và phẫu thuật.

Nhiều bểnh nhân có tăng huyết áp trong tuần đầu và thường sẽ cải thiện, trừ khi có tăng huyết áp từ trước. Tăng huyết áp trong bênh cảnh nhồi máu thận cấp chủ yếu do giải phóng renin, do đó, nếu không có tổn thương thận cấp, tăng kali máu, thì thuốc ức chế men chuyển, chẹn thụ thể angiotensin II là lựa chọn ưu tiên. Trường hợp có tổn thương thận cấp hoặc tăng kali máu, lựa chọn điều trị tăng huyết áp tương tự như các bệnh nhân không có nhồi máu thận.

Điều trị chống đông trong nhồi máu thận bao gồm heparin thường hoặc heparin trọng lượng phân tử thấp phối hợp cùng kháng vitamin $\mathrm{K}$ để đạt đích INR từ 2-3 hoặc cao hơn từ 2,5 - 3,5 nếu có bệnh rung nhĩ hay có van nhân tạo phối hợp. Nếu không có chống chỉ định, chống đông đường uống thế hệ mới cũng là một lựa chọn thay thế cho thuốc chống đông kháng vitamin K. Trong trường hợp có xơ vữa mạch kèm theo, có thể dùng phối hợp cùng Aspirin [5].

Các trường hợp mà khi tiến hành can thiệp sẽ có lợi hơn so với điều trị bảo tồn gồm:

- Tắc hoàn toàn động mạch thận gốc hay nhánh chính động mạch thận $<6$ tiểng hoặc chỉ có 1 thận duy nhất hoặc khi giảm chức năng thận ( MLCT < $50 \mathrm{ml} /$ phút/ $1.73 \mathrm{m2}$ da)

- Tắc không hoàn toàn động mạch thận gốc hay nhánh chính trong vòng 24 giờ

- Tắc không hoàn toàn động mạch thận gốc hay nhánh chính trong vòng 24 giờ hoặc lầu hơn nếu có suy thận, tăng huyết áp mới xuất hiện hoặc nếu có đau vùng hông lưng nhiêu, tiểu máu, sốt.

- Nhồi máu thận do bóc tách động mạch.

Có một số nghiên cứu nhỏ so sánh các lựa chọn điều trị bệnh nhân nhồi máu thận cấp. Nghiên cứu của tác giả Daniel SilverBerg trên 42 bệnh nhân nhồi máu thận, 13 bệnh nhân điêu trị can thiệp và 29 bệnh nhân điêu trị bảo tồn, cho thấy ở nhóm can thiệp sau thời gian theo dõi trung bình 30 tháng, mức lọc cầu thận giảm từ $74-55 \mathrm{ml} /$ phút (giảm 27\%, $\mathrm{p}=0,032$ ) còn ơ nhóm điều trị bảo tồn mức lọc cầu thận giảm từ $66,1-60 \mathrm{ml}$ phút (giảm $9 \%, p=0,04$ ). Nhóm can thiệp có kết quả về mặt hình ảnh tốt hơn và không có tai biến nào ghi nhận giữa các nhóm. Như vậy, nghiên cứu này cho thây, mặc dù đa số bệnh nhân nhồi máu thận nhập viện được điều trị nội khoa nhưng một số bệnh nhân tắc hoàn toàn động mạch thận được điều trị bằng can thiệp mạch thận qua da cho kết quả hình ảnh tốt hơn và đây là lựa chọn điều trị an toàn và nên cân nhắc để cố gắng bảo tồn chức năng thận kể cả khi đã thiếu máu kéo dài [6].

Tuy nhiên, nghiên cứu của Ulrich Blum trên 14 bệnh nhân nhồi máu thận được tiêu sợi huyết qua đường ống thông cho thấy thủ thuật thành công trên 13/14 bệnh nhân nhưng sau thời gian theo dõi hơn 27 tháng, không có sự cải thiện chức năng thận cũng như không cải thiện tưới máu vùng thận nhồi máu [7].

Nhưng cũng ghi nhận những trường hợp tiến hành tiêu sợi huyết qua đường ống thông đạt được kết quả về tưới máu thận, như báo cáo của tác giả K. Cho trên bệnh nhân 51 tuổi, nhồi máu thận, được tiêu sợi huyết bằng Urokinase qua đường ống thông và kết quả cho thấy cải thiện tưới máu thận và không có giảm chức năng thận [8]. Bệnh nhân này của chúng tôi được điều trị hút huyết khối mạch thận, kết hợp với điều trị nội khoa (thuốc chống đông, chống kết tập tiểu cầu và kiểm soát huyết áp) cho kết quả tốt hơn về mặt hình ảnh và sau thời gian theo dõi 3 năm, bệnh nhân vẫn bảo tồn được chức năng thận.

Có lẽ chúng ta cần những nghiên cứu với số lượng bệnh nhân lớn và ngầu nhiên để có thể tìm ra phương án điều trị tối ưu cho bệnh nhân nhồi máu thận.

Tiên lượng sau nhồi máu thận (được điều trị hay không) chưa rõ ràng. Hầu hết bệnh nhân nhồi máu thận có các bệnh lý nền kèm theo, làm tăng nguy cở biến cố và tử vong (rung nhĩ, bệnh tim mạch xơ vữa ) và bệnh nhân nhồi máu thận do thuyên tắc thì thường kèm theo thuyên tắc các cơ quan khác (não, ruột..). Trong nghiên cứu 
theo dõi 44 bệnh nhân nhồi máu thận do rung nhĩ, tỷ lệ tử vong khoảng $11,4 \%$ trong tháng đầu sau khi chẩn đoán. Trong hầu hết các nghiên cứu, nồng độ creatinin ổn định hoặc chỉ tăng nhẹ. Điều này chủ yếu do thận còn lại không bị ảnh hưởng hoặc phần nhu mồ thận còn lại phì đại bù trừ [9].

\section{KẾT LUẬN}

Nhồi máu thận là bệnh lý hiếm gặp trên lâm sàng và thường bị bỏ sót do biểu hiện lâm sàng không đặc hiệu. Trước một bệnh nhân có biểu hiện lâm sàng là đau hông lưng kèm theo buồn nôn/ nôn và có nguy cơ thuyên tắc, huyết khối thì cần nghĩ tới nhồi máu thận. Lựa chọn điều trị còn chưa rõ ràng, tùy thuộc vào kinh nghiệm và nguồn lực của trung tâm, đặc điểm bệnh nhân. Trong những bệnh nhân phù hợp, can thiệp mạch thận qua đường ống thông có thể là một lựa chọn điều trị nhằm cố gắng bảo tồn chức năng thận, phối hợp với điều trị thuốc chống chống đông và/hoặc thuốc chống kết tập tiểu câu.

TÀI LIỆ THAM KHẢO
1. Paris, B., et al., Blood pressure and renal outcomes in patients with kidney infarction and hypertension. J Hypertens, 2006. 24(8): p. 1649-54.

2. Saeed, K., Renal infarction. Int J Nephrol Renovasc Dis, 2012. 5: p. 119-23.

3. Korzets, Z., et al., The clinical spectrum of acute renal infarction. Isr Med Assoc J, 2002. 4(10): p. 781-4.

4. Hassanein, M., et al., Renal artery embolism successfully managed by ultrasound enhanced catheter directed thrombolysis. Egypt Heart J, 2018. 70(4): p. 447-450.

5. Delezire, A., et al., Acute renal infarction: longterm renal outcome and prognostic factors. J Nephrol, 2021. 34(5): p. 1501-1509.

6. Silverberg, D., et al., Acute renal artery occlusion: Presentation, treatment, and outcome. J Vasc Surg, 2016. 64(4): p. 1026-32.

7. Blum, $\mathbf{U}_{\text {., }}$ et al., Effect of local low-dose thrombolysis on clinical outcome in acute embolic renal artery occlusion. Radiology, 1993. 189(2): p. 549-54.

8. Arabi, M., R. Vellody, and K. Cho, Acute Renal Artery Occlusion with Prolonged Renal Ischemia: A Case of Successful Treatment with Stent Placement and Catheter-directed Thrombolysis. J Clin Imaging Sci, 2011. 1: p. 11.

9. Hazanov, N., et al., Acute renal embolism. Fortyfour cases of renal infarction in patients with atrial fibrillation. Medicine (Baltimore), 2004. 83(5): p. 292-299.

\section{TỔN THƯƠNG DA TRÊN BỆNH NHÂN XƠ CỨNG Bì HỆ THỐNG TIẾN TRIỂN VÀ MộT Số YẾU Tố LIÊN QUAN}

\section{TÓM TẮT.}

Mục tiêu: Mô tả đặc điểm tổn thương da và một số yếu tố liên quan ở bệnh nhân xơ cứng bì hệ thống. Nghiên cứu mố tả cắt ngang trên 60 bệnh nhân điều trị nội trú tại trung tâm Dị ứng - Miễn dịch lâm sàng Bệnh viện Bạch Mai từ tháng 7/2020 đên tháng 9/2021. Bệnh nhân đủ tiêu chuẩn chẩn đoán theo bộ tiêu chuẩn của ACR/EULAR 2013. Kết quả nghiên cứu cho thấy tổn thương lâm sàng đa dạng, đặc biệt là các tổn thương da ở bệnh nhân xơ cứng bì hệ thống, tất cả bệnh nhân đều có hiện tượng dày da với mức độ dày da trung bình của nhóm nghiên cứu là 14,5 $\pm 7,9$, hiện tượng Raynaud $(73,3 \%)$, thay đổi sắc tố da $(5 \dot{3}, 3)$, rụng tóc $(46,7 \%)$, loét đâu chi $(31,7 \%)$, hoại tử đâu chi $(28,3 \%)$, sẹo lõm đầu chi $(11,7 \%)$, loét da $(33,3 \%)$, telangiectasisa $(13,3 \%)$, calcinosis $(18,3 \%)$. Nhóm bệnh nhân nghiên cứu có tî lệ tổn thương nội tạng cao với bệnh phổi kẽ/xơ phổi çién $81,7 \%$, tổn thương tiêu hóa $37 / 60(61,7 \%)$ và tổn thương tăng áp

*Trường Đại học Y Hà Nội

Chịu trách nhiệm chính: Vũ Thùy Linh

Email: vulinhhmu@gmail.com

Ngày nhận bài: 20.9.2021

Ngày phản biện khoa học: 15.11.2021

Ngày duyệt bài: 26.11.2021

\section{Vũ Thùy Linh*, Hoàng Thị Lâm*}

lực động mạch phổi 36/60 (60\%). Tỉ lê gặp tổn thương thận thấp nhất lần lượt với viêm cẩu thận và khủng hoảng thận là $13,3 \%$ và $5 \%$. Các bệnh nhân được làm xét ngiệm kháng thể kháng nhân đều cho kết quả dương tính, kháng thể Scl-70 dương tính chiếm $67,9 \%$, kháng thể anti-centromere dương tính là $31,3 \%$. Kết luận: Tổn tương da ở bệnh nhân xơ cứng bì hệ thống là các triệu chứng đặc trưng, quan trơng, là biểu hiện thường gặp nhất trong các thương tổn cúa XCBHT và thường được nhận ra trước các biếu hiên toàn thân giúp các bác sĩ hướng tới chẩn đoán. Các tổn thương da có thể gây ra sự khó chịu đáng kể (ngứa dai dẳng, mất sắc tố, vết loét hở gây đau đớn, ành hưởng tới chất lượng cuộc sống và thẩm mỹ); Những bệnh nhân có tiền sử tổn thương đầu chi, có
nguy cơ tái phát, để lại biến chứng cao, vì vậy việc phân tầng bệnh nhân có các yếu tố nguy cơ liên quạn đến tổn thươning để quản lý tốn thương hoại tử đâu chi nói riêng và các tốn thương da nói chung là quan trong để có phương pháp điều trị bệnh kịp thời, hợp lý

Tư khóa: xơ cứng bì hể thống, hoại tử đầu chi, hiện tượng Raynaud, thay đổi sắc tố da, rụng tóc, hoại tử đâu chi, bệnh phổi kẽ, tăng áp lực động mạch phổi

\section{SUMMARY \\ CHARACTERISTIC AND RISK FACTORS FOR SKIN LESIONS IN PATIENTS WITH}

